\title{
住宅照明環境が高齢者に与える心理的影響に関する研究 DIVERSITY OF A MENTAL PROCESS ON THE LIGHTING EFFECTS FOR ELDERLY PERSONS
}

\author{
石橋 英里子*, 八藤後 猛**, 野 村 歡*** \\ Eriko ISHIBASHI, Takeshi YATOGO and Kan NOMURA
}

\begin{abstract}
The purpose of this study is to suggest to comfortable lighting environment design for the elderly persons. We conducted the following experiment to collect the data. The testee were three groups, they are young, manhood, and elderly persons. We present 14 lighting scene to the experimental.

An evaluation presents some factors, which are named Comfort, Activity, Cleanness, Stillness. The young people feel comfortable only the scene of Comfort, but elderly persons feel Activity in mainly. My interprets this result as difference of comfortable lighting environment between young people and elderly persons are affected a mental process rather than difference of visual function.
\end{abstract}

Keywords : lighting effects, elderly persons, a mental process,living room,factor analysis environmental assessments

照明効果，高齢者，心理的影響，居間，因子分析，環境評価

\section{1.はじめに}

高齢社会が急速に進みつつある現在、高齢者に快適な視環境を提 供するための多くの研究がなされている。これらの研究は、ランド ルド環や色標等の視対象物と、それを見るために必要な背景輝度・ 照度レベル等の関係を求めるなど、高齡者の視認能力に関寸るもの がほとんどである。公的機関や民間企業が建設している高齡者用住 宅に関する事例調查においても、照明に対する配慮は少なく、明確 に把握でき、設計にも関連させやすい量的な「照度レベル」評価に 偏りがちである。照明に関して多くの指針等がほぼ共通して言及す る唯一の項目は照度レベルであり、通常のレベルをいくぶん増加す る（住宅の場合 $150 〜 2001 x$ 程度）ことを推奖している1)。しかし 本来ならば、照明の目的は、ものがよく見える明視の要求を満たす ためだけではなく、とくに住空間においては照明環境における心理 的快適性が重要であると考えられる。

視環境に関する高齢者の特性として、福田他 ${ }^{2)} に よ り$ 明暗の調節 応答機能の低下など、機能面の特性については、先行研究がある。 しかし、これで高龄者の視点からみた照明の心理的影響に関する 研究は少ない。

本研究は、加龄により視機能が低下してくると考えられる高齢者 に対し、実空間で照明器具の組合せや光色・照度レベルを種々変化 させた条件下で感覚評価実験を行い、住宅のリビングにおける、高
齢者にとって快適な照明条件を提案することを目的としている。

「心理的快適性」を評価する研究として、長町他 ${ }^{3)}$ とよる情緒工 学的研究において照明実験室を用いた研究がなされ、「照度感」に ついては、同照度であっても器具の種類、配置条件によって異なる ことなどが示唆されている。また、小林他)では、輝度分布が室内 の明るさ感に影響を与え、不均一さが室内の明るさ感に影響を及す としている。北村他 ${ }^{5,6)}$ 、宮澤他 ${ }^{7)}$ 、中島他 ${ }^{8)}$ 、石神他 ${ }^{9)}$ ものこと を裏付けたうえで、とくに北村他 ${ }^{5,6)}$ 、宮澤他 ${ }^{7)}$ 、中島他 ${ }^{8)}$ ではこう した明るさの分布が人間行動に影響していることを示唆している。

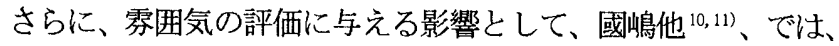
光源の種類や照度の他、壁材のテクスチャーやカーテンといった、 仕上げ材の影響がこれらの評価に影響を及ぼすとされている。

したがって、本研究のように、心理的快適性を評価するための室 内空間や照明の設定については、こうした影響について考慮される ベきである。

\section{2. 研究方法}

\section{2-1 評価実験方法}

実験・解析は図1のSD法フローによって行った。評価実験は、前 項より器具の種類や分布によって照明に関寸る評価が大幅に変わる こと、照明以外の内装等による心理的影響は無視できない。しか し、これらを標準化した空間は現在示されていないこと、仮にあっ
* 元日本大学大学院 大学院生・工修

** 日本大学理工学部建築学科 助手・工修

*** 日本大学理工学部建築学科 教授・ 工博
Graduate Student, College of Science \& Technology, Nihon Univ., M. Eng. Research Assoc., College of Science \& Technology, Nihon Univ., M. Eng. Prof., College of Science \& Technology, Nihon Univ., Dr. Eng. 


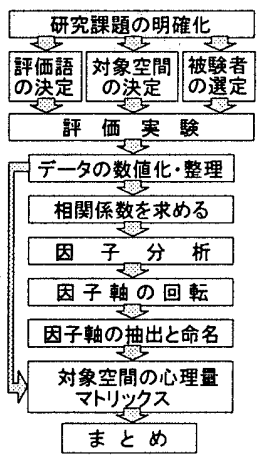

図 1 SD法つ口一

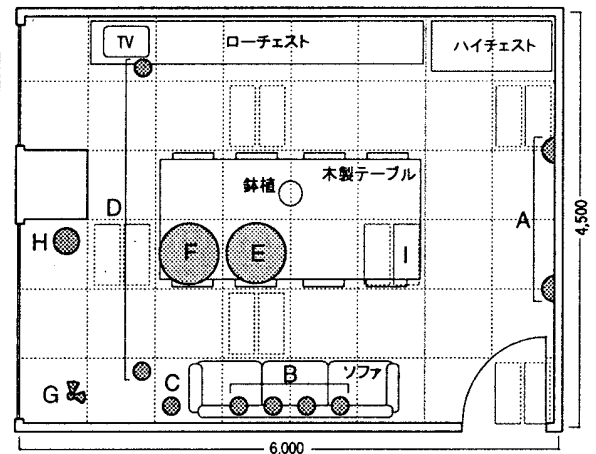

図 2 実験室平面·照明配置図

表 1 実験に用いた照明器具と照明パターン

\begin{tabular}{|c|c|c|c|c|c|c|c|c|}
\hline & \multicolumn{3}{|c|}{ 取 付方法 } & \multicolumn{4}{|c|}{ 照明光源 } & 色温度 \\
\hline A & \multicolumn{3}{|c|}{ 壁直付·血形乳白汃－ } & \multicolumn{4}{|c|}{ 白色染装電球 $60 \mathrm{~W}$} & $2800 \mathrm{~K}$ \\
\hline $\mathrm{B}$ & \multicolumn{3}{|l|}{ ダウンライト } & \multicolumn{4}{|c|}{ 白色筌装電球 $60 \mathrm{~W}$} & $2800 \mathrm{~K}$ \\
\hline C & \multicolumn{3}{|l|}{ ダウンライト } & \multicolumn{4}{|c|}{ コンパ外形三波長形尽白色蛍光シンプ 18W } & $5000 \mathrm{~K}$ \\
\hline D & \multicolumn{3}{|l|}{ ダウンライト } & \multicolumn{4}{|c|}{ 白色塗装電球 $60 \mathrm{~W}$} & $2800 \mathrm{~K}$ \\
\hline$E$ & \multicolumn{3}{|c|}{ 天井直付·環形乳白汃一 } & \multicolumn{4}{|c|}{ 罾形三波長形昼白色虽光ランプ 30W·38W } & $5000 \mathrm{~K}$ \\
\hline $\mathrm{F}$ & \multirow{2}{*}{\multicolumn{3}{|c|}{ 天井直付·環形乳白汃一 }} & \multicolumn{4}{|c|}{ 白色塗装電球 $60 \mathrm{~W}(\times 4)$} & $2800 \mathrm{~K}$ \\
\hline G & & \multicolumn{2}{|c|}{ 置き形・フロアスタンド } & \multicolumn{4}{|c|}{ 白色小型列プトン電球 $60 \mathrm{~W}(\times 2)$} & $3000 \mathrm{~K}$ \\
\hline $\mathrm{H}$ & \multicolumn{3}{|c|}{ 置き形·フロアスタンド } & \multicolumn{4}{|c|}{ 白色鉒装電球 $60 \mathrm{~W}$} & $2800 \mathrm{~K}$ \\
\hline 1 & \multicolumn{2}{|l|}{ 天井埋込形 } & & \multicolumn{4}{|c|}{ 直管ツイン形三波長形量白色蛍光ランプ $55 \mathrm{~W}$} & $5000 \mathrm{~K}$ \\
\hline & \multicolumn{2}{|c|}{ 天并拡散照明なし } & \multicolumn{3}{|c|}{ 天井拡散照明が堂光灯 } & \multicolumn{3}{|c|}{ 天井拡散照明が白啝灯 } \\
\hline ype & 組合せ & 照度 $\mathrm{Ix}$ & Type & 組合せ & 照度 $\mathrm{Ix}$ & Type & 組合せ & 照度 $1 \mathrm{x}$ \\
\hline 1 & $\mathrm{~A}+\mathrm{G}+\mathrm{H}$ & 36 & 5 & $E$ & 167 & 9 & $F$ & 40 \\
\hline 2 & $\mathrm{~A}+\mathrm{B}+\mathrm{G}+\mathrm{H}$ & 200 & 6 & $E+A$ & 181 & 10 & $F+A$ & 55 \\
\hline 3 & $A+D+G+H$ & 53 & 7 & $E+C$ & 190 & 11 & $\mathrm{~F}+\mathrm{A}+$ & 80 \\
\hline 4 & $A+B+D+G+H$ & 213 & 8 & $\mathrm{E}+\mathrm{A}+$ & 205 & 12 & $F+A_{+}$ & 99 \\
\hline & $-\mathrm{m}$ & & 0 & 1 & 917 & 13 & $F+B$ & 201 \\
\hline
\end{tabular}

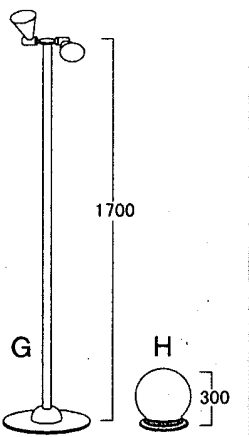

図3 照明器具

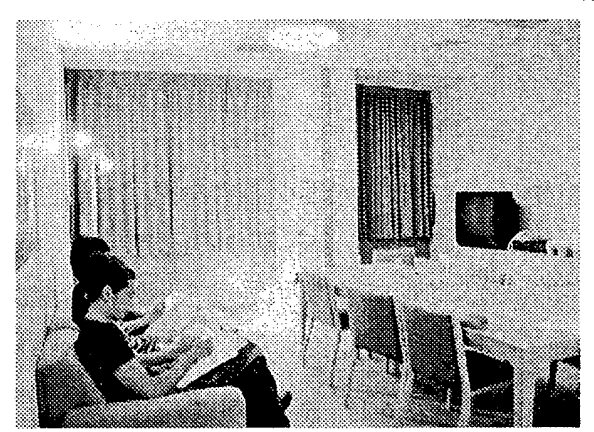

図 4 実験風景
たとしても一般住宅のリビングルームの環境とは異なる実験環境と なることが考えられる。したがって、本実験ではある程度一般的な 住宅環境を維持しながらも多様な照明環境を提示できる、メーカー のモデルルームを使用した。また、モデルルームの使用について は、長町他 ${ }^{3)}$ のうに、照明ごとの評価をシーンごとの相対的な感 覚評価と位置づけることによる比較法を用いることで、本研究目的 に合ったデータが得られると考えた。

そこで、実験はこれらの要件を満たす、東京都新宿区にある住宅 メーカーの照明環境室において、1996年9月から12月において実 施した。図2に示す住宅のリビングを想定した幅 $4.5 \mathrm{~m}$, 奥行 $6.0 \mathrm{~m}$, 天井高 $2.6 \mathrm{~m}$ の室内で、表 1 および図 3 に示す 9 種類の照明器具を用 いて組合せが異なる14の照明パターンを設定した。実験室内は、外 光が入らない状態とした。

実験においては、1〜3名の被験者をソファに着席させ、14の照 明パターンを 1 つずつ提示し、リビングにおける照明環境に対寸る 印象について、表 2 に示寸 25 の形容詞対による評価語を用いて D法による7段階の評価を行った。さらにこれらの評価とともに、 各照明パターンに対する好み〈好き一嫌い〉の7段階評価を行った。 形容詞対の選択、ならびに段階の設定については高㱓者に対して予 備実験を行い、同一の環境における再現性を検討した結果、この点 に関してとくに問題はなかった。

評洒時間はとくに設定せず、全員が 1 つ照明パターンの評価を 終えた時点で、全ての照明を消灯した状態で 30 秒待機し、次の照 明パターンを提示した。実験風景を図 4 に示す。

\section{2-2 被験者}

感覚評価実験は、21 歳から77歳の年齢層に执いて、男性 27 名、 女性22名、計49名に対して行った。年齢による評価の違いに対す る比較検討を行うことを目的とし、20代の 16 名（男 10，女6）を 青年層、40～50代の 16 名（男6,女 10）を壮年層、65歳以上の 17 名（男 11，女6）を高齢層として、被験者を分類した。

表 2 実験における評価語、照明タイプ別評定平均値（対象：全ヶース）（-3〜+3の7段階）

\begin{tabular}{|c|c|c|c|c|c|c|c|c|c|c|c|c|c|c|}
\hline 照明タイプ( & 0 & 1 & 2 & 3 & 4 & 3 & 6 & 7 & 8 & 9 & 10 & 11 & 12 & 13 \\
\hline 月るいー暗い & 2.76 & -0.89 & 1.40 & -0.82 & 1.68 & -0.17 & 0.87 & 0.31 & 1.60 & -1.52 & -0.04 & .42 & 1.70 & 0.94 \\
\hline 一冷たい & 0.23 & 1.15 & & 0.65 & & 20 & & & & 0.31 & & & & \\
\hline 一固い & & 1.27 & & 0.84 & & 3 & 0.47 & -0 & & 0.54 & & & & \\
\hline いいー眩しい & & 1.89 & -0.12 & 1.11 & -0.44 & -1 & 0.33 & 0 & -0.05 & 1. & 1 . & & -0.30 & -0. \\
\hline 一地味な & 1.50 & -0.92 & 0.27 & -0.89 & 0.52 & -0.33 & -0.09 & -0.54 & 0.75 & -1.40 & 0. & 0 & & 0.0 \\
\hline 乡な一重圧な & 1.60 & -0.13 & 0.47 & -0.21 & 0.68 & 0.13 & 0.51 & 0.13 & 0.67 & -0.98 & -0 . & & 3 & 0.0 \\
\hline 万る一安らぎの & -0.61 & 1.41 & 0.63 & 0.88 & 0.52 & -0.90 & 0.22 & -0. & & 0.69 & & & & \\
\hline - 堅張 & -0.79 & 1.23 & 0.35 & 0.61 & 0.31 & 0.97 & 0.15 & -0 . & & 0.69 & 0 . & & & \\
\hline E一野暮 & 0. & 0.37 & 0.69 & 0.32 & 0.58 & -0.08 & 0.05 & -0 . & 58 & -0.42 & 0 . & & 0.45 & 0.2 \\
\hline か一寂しい & 1.71 & -0.41 & 0.54 & -0.47 & 0.94 & 1.02 & 0.13 & -0.74 & 1 & 0.93 & -0 . & & .22 & 0.8 \\
\hline 々下一狭苦しい & 1.66 & 0.20 & 0.29 & 0.11 & 0.57 & -0.43 & 0.18 & -0.18 & .73 & -0.59 & 0. & 8 & .75 & -0.1 \\
\hline すんだ & 2.00 & -0.32 & 0.46 & -0.33 & 0.61 & 0.17 & $0.1-1$ & -0 . & 0.87 & -0.89 & -0 & & & \\
\hline -居心わるい & 0.16 & 1.47 & 0.89 & 0.76 & 0.93 & -0.81 & 0.41 & -0.54 & 91 & 0.27 & 1 & & 1.5 & 0.8 \\
\hline 氢な & 0.42 & 0.15 & 0.36 & 0.0 & 0.76 & -1.10 & -0.12 & -0.81 & 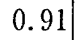 & -0.57 & 0. & & 0.95 & -0.0 \\
\hline 一陰気な & 1.62 & -0.05 & 0.89 & -0.22 & 0.94 & -0.73 & 0.01 & -0.72 & .30 & -0. & & & 9 & 0.3 \\
\hline 口付 & 1.23 & 0.13 & 0.29 & 0.1 & 0.45 & -0.64 & 0.10 & -0.34 & .94 & -0 & 0. & 4 & & -0.2 \\
\hline & 0.24 & 1.0 & 0.68 & 0.4 & 0.52 & -0.26 & 0.26 & -0.03 & 0.68 & 0. & & & & 0. \\
\hline 一不 & & 0.61 & 0.93 & 0.5 & 0.73 & 0.40 & 0.58 & 0.26 & 0.92 & -0 . & r & & 0.9 & 0.3 \\
\hline 7 & & & 0. & 0. & 0. & -0.5 & 0 . & -0 . & & 1 & & & .5 & 0.1 \\
\hline 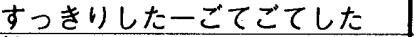 & & 0.59 & 0.67 & 0.36 & 0.54 & 0.50 & & 0. & & J & & & .57 & \\
\hline かなーうるさい & -0.14 & 1.71 & 0.43 & 1.01 & 0.32 & 0.62 & 0.37 & 0. & 0.07 & 1.08 & & 0 & 0.25 & 0.3 \\
\hline & -0.03 & -0.14 & 0.21 & -0.21 & 0.57 & -0.91 & -0.30 & -0.72 & 0.77 & -0.73 & 0. & 0. & 0.71 & -0.0 \\
\hline & & & 0. & -0.3 & 0.7 & 0. & 0. & 0.2 & 1. & -1.05 & -0 & & 97 & \\
\hline$\pi$ & 0.2 & 1. & 0. & 0.54 & 0.5 & -0 . & -0 . & -0.57 & 0.84 & 0 . & & & .87 & 0.2 \\
\hline なーうっとうしい & 0.96 & 0.27 & 0.36 & 0.02 & 0.47 & 0.27 & 0.10 & 0.13 & 0.68 & -0.31 & 0.32 & 0.81 & 0.48 & 0.0 \\
\hline
\end{tabular}


表 3 因子分析結果
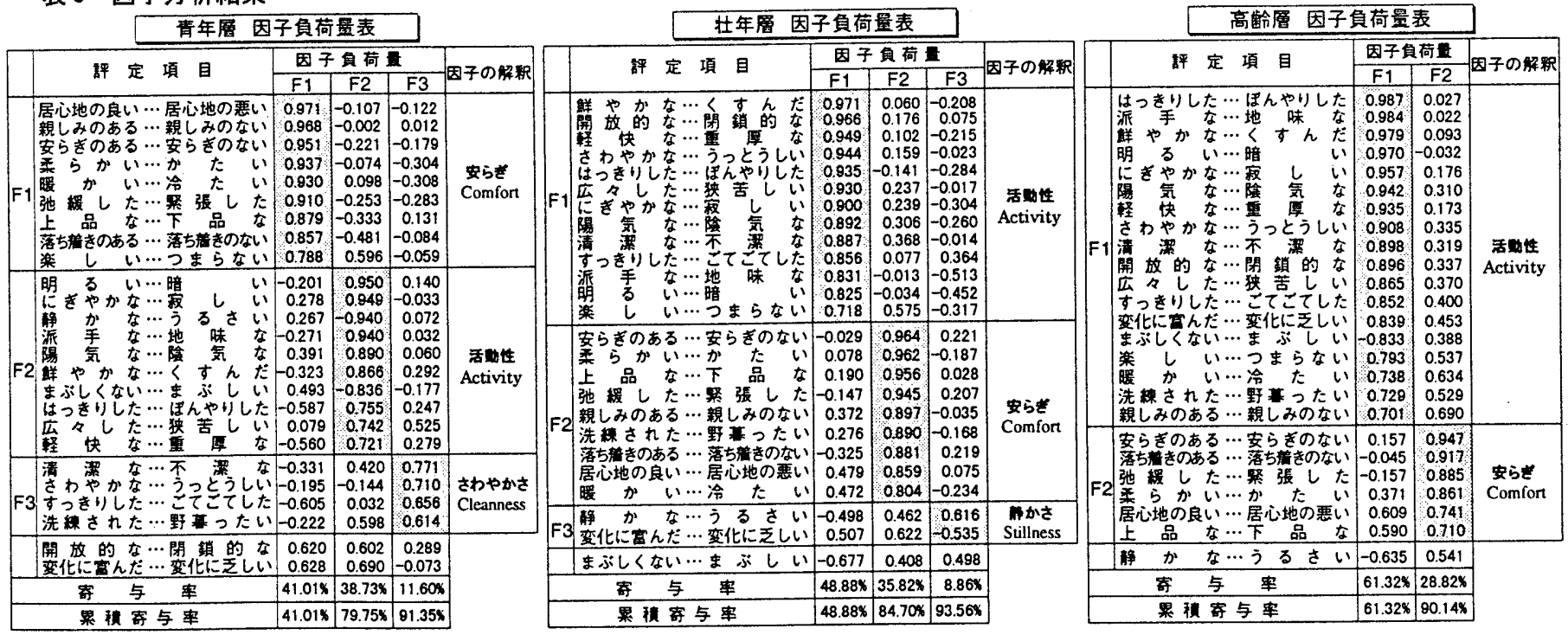

表4 各評洒語評定値と好みの評定値の相関係数

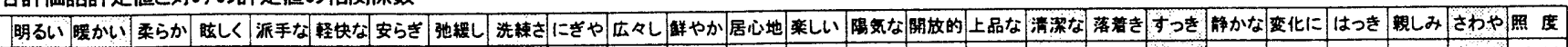

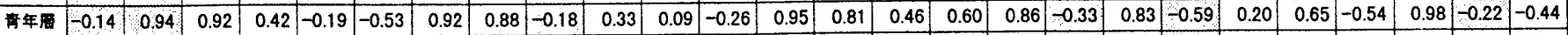

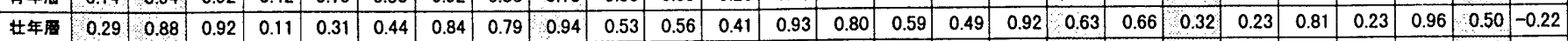

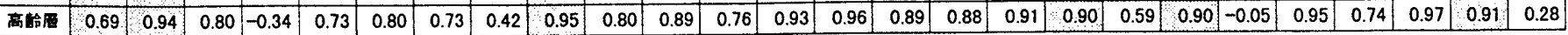

\section{3. 結果}

以下の解析には、統計解析ソフトウェアSPSS Ver6. 1J Windows 版を用いた。

3-1 基本データと有意差検定

本実験において、(照明パターン数 14）×（被験者数 49）×（評 価語数 $25+$ 好みの評価) のデータが得られた。その後、全被験者の 評価值のチェックを行い、連続して同じ評価值とするといった、特 異な評価を行う被験者のデータを排除した。

調整後のデータを用いた照明パターンごとの評定平均值によるプ ロフィルを表 2 に示寸。これによると、全照明パターンの平均值が ほぼ中央に集まっていることがわかる。これは全対象空間が適切な バランスで設定されていると考えられる。

次に、各年齢層 (以下、各層と略す) の評価語ごとの評定平均值 について、(照明パターン数 14) × (評価語数 25) × (2つの年齢 層の組合せ3）に対して有意水準5\%で差の検定を行ったところ、有 意差があると判定された評価語の数が、青年層と壮年層で 81 語、壮 年層と高齢層で 31 語、青年層と高龄層で 117 語あった。

\section{3-2 因子分析結果}

25の形容詞対による評価語に対する青年層の評定平均值につい て因子分析 (バリマックス回転)を行い、因子軸を抽出したところ、 3つの因子が得られた。表3にその結果を示す。各因子に含まれる 形容詞の内容加ら、第 1 因子を「安らぎ」第2因子を「活動性小 第3因子を「さわやかさ」と名付けた。第1因子から第3因子まで の累積寄与率は $91.35 \%$ となり、室内の照明環境が青年層の居住者 に与える心理的影響はこれら3つの因子により説明できるものと考 えられる。

同様に、壮年層の評定平均值に対して因子分析を行ったところ、 3 の因子が得られ、第1因子を「活動性、第2因子を「安らぎ」、 第 3 因子を「静かさ」と名付けた。第 1 因子から第 3 因子までの累
積寄与率は $93.56 \%$ であった。高齢層の評定平均值に対寸る因子分 析では、2つの因子が得られ、第1因子を「活動性小、第2因子を「安 らぎ」と名付けた。第1因子から第2因子までの累積寄与率は $90.14 \%$ であった。

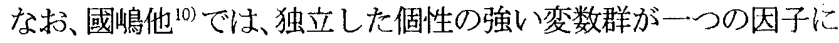

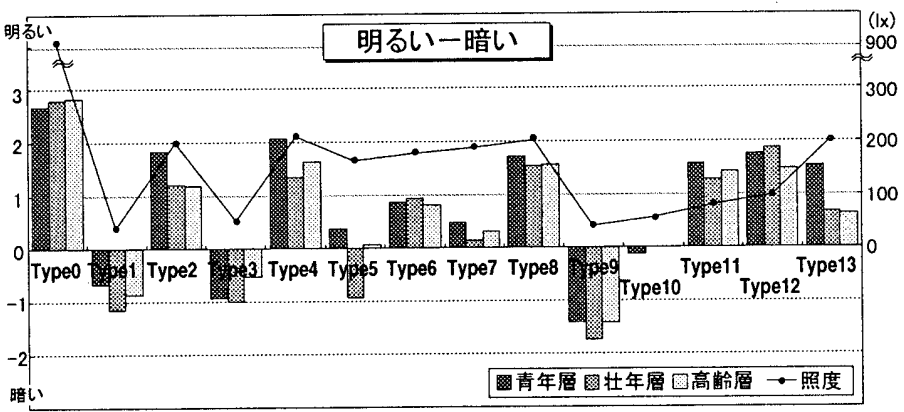

図5〈明るい一暗い〉の各年秢層評定平均値と照度レベル

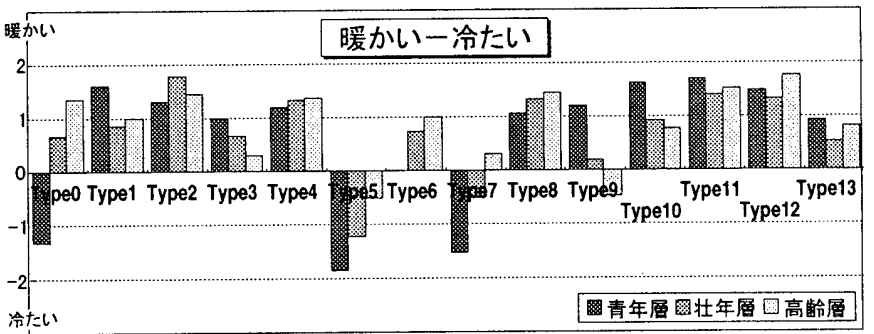

図6〈暖かいー冷たい〉の各年齢層評定平均値

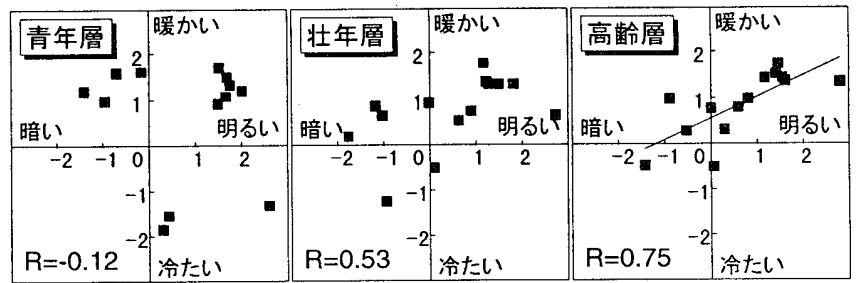

図7 年齿層別明るさ感と暖かさ感の関係 
おいてみられ、それを「評価対が空間 自体の総合的な評価を表す evaluation 因子」として設定しているが、本実験 ではそのような因子はなかった。

ここで得られた各層の因子と評価語 評定値をもって、各照明パターンによ る室内の雾囲気に対する各層の「理 量」とし、年齢層による違いを比較検 討していく。

\section{4. 照明瓄境に対する心理量における 年齢層比較}

4-1 各評価語評定值

室内の照明環境に関する各層の心理 構造を明らかにするために、評価語間

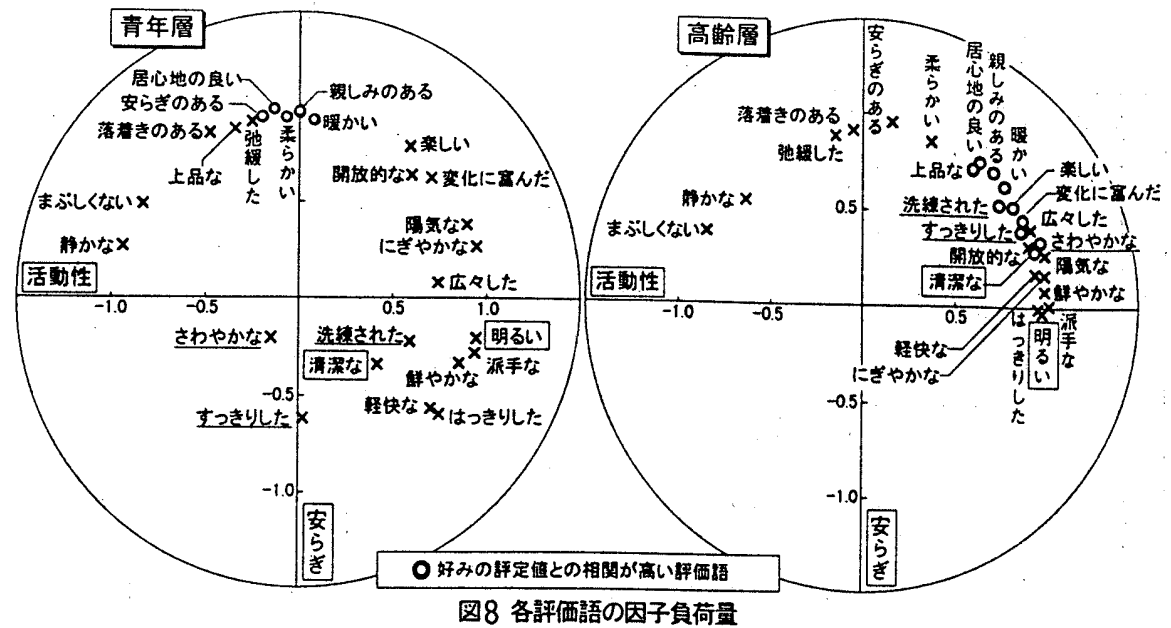

の関保を求める際に、照明環境に対する評価に执て代表的な事項 であると考えられる評価語〈明るい〉の評定値に着目した。表4に 示寸好みの評価との相関をみると、年齢層によって違いがみられる が、図5に示寸各層の評定平均值と有意差検定結果をみると、各層 の間に明るさ感における違いはほとんどないことがわかる。照度レ ベルとの関倸をみると、Type5, 7, 13のように天井からの照明のみの パターンは高照度であるにもかかわらず明るさ感が得られていな い。また、各層ともに好みとの相関が高い評価語〈暖かい〉の評定 值に着目し、図6に各層の評定平均值を示す。これをみると、青年 層では蛍光灯のみを用いた色温度の低い照明パターン Type 0, 5, 7 は、すべてマイナスの值であるが、高齢層では異なる結果を示して いる。そこで図7に示寸明るさ感との関係をみると、年齢層が高く なるにしたがい、相関が高くなることがわかる。

さらに、明るさ感と他の評価語との関倸を明確にするため、各層 に共通して抽出された「活動性」因子を $\mathrm{x}$ 軸、「安らぎ」因子をy にとった因子空間上に各評価語の因子負荷量をプロットしたものを 図8に示寸。なお、これらの因子の名称は同じものとなったが、構 成される変数はすべて同じでなく、また異なる母集団から得られた 因子どうしを同一次元で取り扱うことには厳密には問題がある。し かし、これらは「活動性」「安らぎ」といった傾向を表している点 では共通していること、これらを代表変数として扱い、相互に比較 することは、下記の結果のように年齢層間の比較・分析に有効こと から、あえて因子比較を行った。因子得点についても、同様に比較 分析を行った。

これをみると、評価語〈清潔な〉は高齢層の因子空間上での位置 が青年層と大きく異なり、〈明るい〉と の関倸が強くなっていることがわか る。また、表4からわかるように、清 潔な〉と好みとの関倸は、青年層で相 関倸数 $\mathrm{R}=-0.33$, 壮年層 $\mathrm{R}=0.63$, 高齢層 $\mathrm{R}=0.90$ と、年龄層が高くなるにした がって、相関が高くなる。くっっきり た〉〈さわやかな〉洗練された〉にも 同様の傾向がうかがえる。れらのこ とから、青年層では明るさ感と好みの 関係は薄いが、年齢が上がるにした

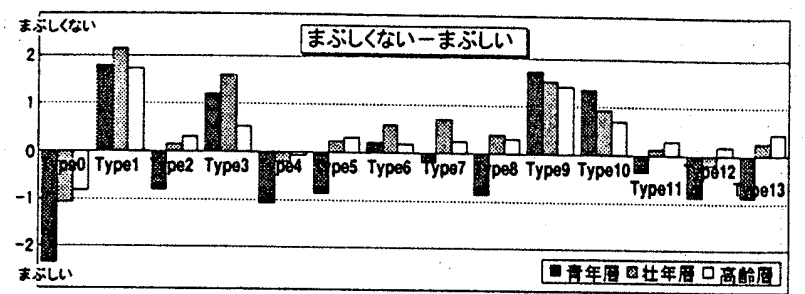
图 9 〈ま゙しくないーまぶしいの各年榆層評定平的値

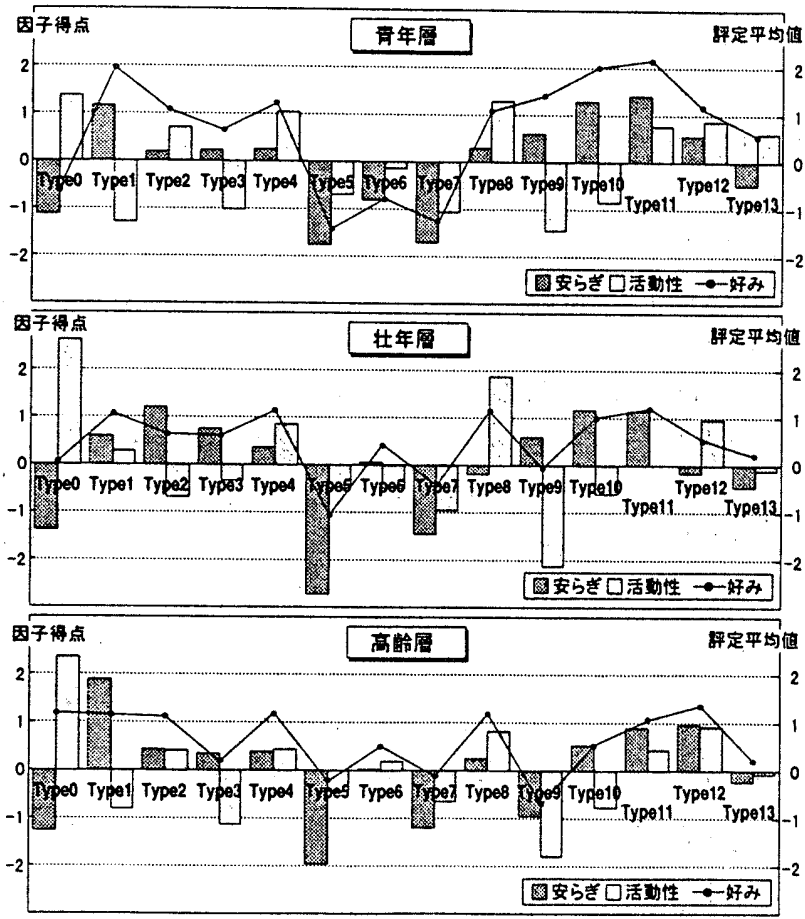

图10 年卙層別「安らぎ活動性、因子得点と好みの評定平均値

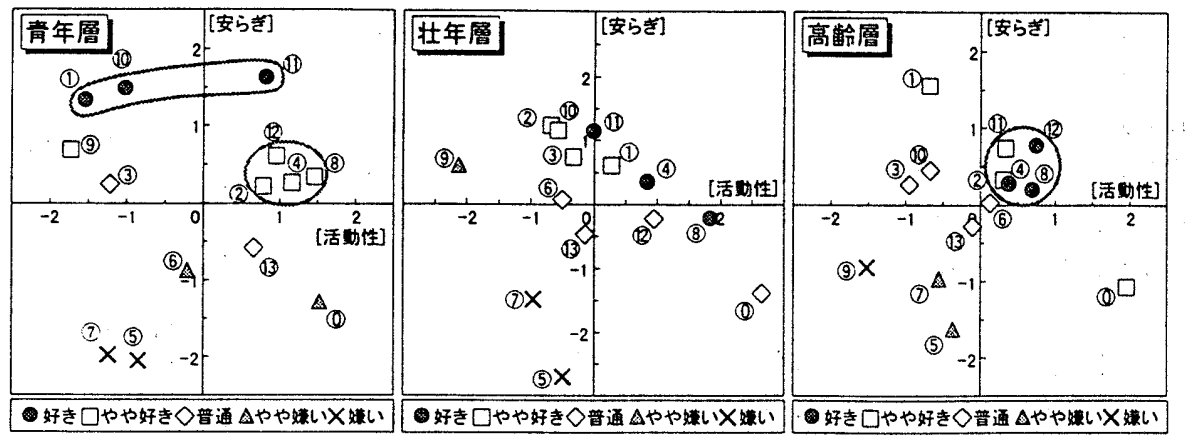

图11 年䧻層別各照明パターンの因子得点と好みの関係 
がって明るさ感は暖かさ、清潔感につながり、それが好みに大きく

影響してくると考えられる。

また、高齢者は眼球水晶体の白濁化によって眼球内で光の散乱が 生じ、青年よりもグレアを感じやすいため、高齢者配慮の照明とし て不快グレアの防止が重要とされている。そこで評価語〈まぶしく ないりに着目寸ると、図9からわかるように、本実験においては青 年層が頭上からのダウンライトや蛍光灯を用いた照明パターンの評 定平均值がマイナスであるのに対し、壮年層、高齢層ともにType0 以外ではプラスの值を示しており、光源が露出していない状態での 2001x程度の照度レベルの照明に対してはグレアを感じていないと 考光た。

\section{4-2 各因子得点と照明条件}

14の照明パターンと、各層に共通する「安らぎ」活 動性」の各因子との関係を因子得点により検討する。 各層の「安らぎ」「活動性」因子得点と好みの評定平均 值を図 10 に示す。

「安らぎ」因子をみると、青年層では白熱灯のみを用 いたパターン Type1, 9, 10, 11 の得点が高いが、高龄層 では少灯照明で照度レベルの低いType9, 10はこれと比 較して大幅に得点が低くなる。青年層、高龄層ともに B 及びD のダウンライトを点灯したパターン Type2, 3, 4, 13の得点は比較的低くなる。「安らぎ」と照 度レベルとの相関は、各層とも $\mathrm{R}=-0.4$ 程度の值となっ ている。

「活動性」因子は、各層とも白熱灯・蛍光灯の種類に かかわらず、4種類以上の照明器具を用いた多灯照明 であるパターンの得点が高いが、多灯照明でも照度レベルの低い Type3 は得点が低い。この傾向は各層とも同様であるが、壮年層、 高龄層ではType0の得点が極端に高い結果となっている。照度レベ ルとの関係をみると、青年層で $\mathrm{R}=0.53$, 壮年層 $\mathrm{R}=0.66$, 高齢層 $\mathrm{R}=0.77$ と、年齢層が高くなるにしたがって相関が高くなる。 4-3 各因子と好办の関係

各層における因子と好みとの関係を明らかにするため、「活動性」 因子と「安らぎ」因子の因子空間上に各照明パターンの因子得点を プロットしたものを図 12 に示す。図中の丸数字はTypeを表してお り、各層好みの評定平均值の高いものから順に、[好き] [队や好き] [普通][队队嫌い] [嫌い] の5つにグループ化している。これを みると、青年層では「安らぎ」の得点が 1.0 以上の照明パターンは すべて〔好き]グループに属している。「活動性」が高いものも好 まれる傾向がみられるが、「安らぎ」がマイナス方向であるものは 好みの評価が低い。壮年層では、「安らぎ」が高いものが好まれる 傾向がややみられるが、好みのグループは混在した結果となってい る。高齢層では「安らぎ」活動性」両因子ともにプラス方向にあ るものが好まれている。また、Type0やType1のように、いずれか の因子得点が際立って高忆ば、もう1つの因子得点が低くても好 みの評価嚆い。各層とも、安らぎ」「活動性」ともに低いものは 好みの評価が低いことがわかる。

また、「安らぎ」因子得点と好夕の評価との関係を図 12 に、「活 動性」因子得点と好みの評価との関係を図 13 にそれぞれ示す。こ れをみると、「安らぎ」は、青年層では $\mathrm{R}=0.98$ と高い值を示してい

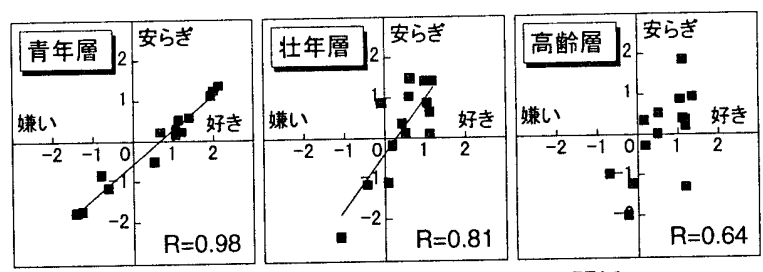

図12 年路層別「安らき」因子と好みの関係

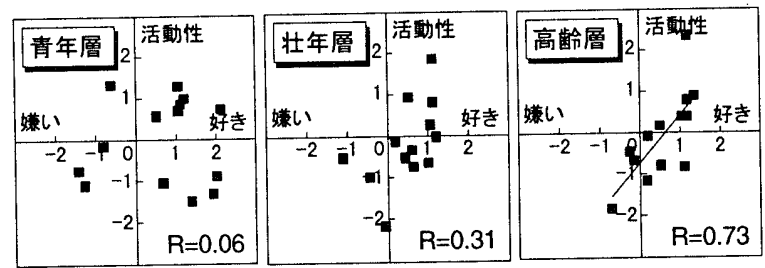

図13 年齢層別「活動性」因子亡好みの関係

表 5 重回帰分析結果

\begin{tabular}{|c|c|c|c|c|c|c|c|c|c|c|c|}
\hline & \multicolumn{5}{|c|}{ 偏 回慢係 数 } & \multicolumn{4}{|c|}{$\begin{array}{l}F \\
\end{array}$} & \multirow{2}{*}{$\begin{array}{l}\text { 重相䦗 } \\
\text { 俰 }\end{array}$} & \multirow{2}{*}{ 溸㩯 } \\
\hline & 要ら艺 & 活動性 & 茯やかさ & 静かさ & 定数愐 & 安ら芒 & 活動性 & 茞やかさ & 静かさ & & \\
\hline 转年層 & 1.1383 & 0.0707 & -0.0202 & & $0.649^{* 5}$ & 290.62 & 1.13 & 0.09 & & 0.98 & 0.96 \\
\hline 壮年層 & 0.5358 & $0.289^{* *}$ & & -0.0277 & $0.466^{*} 7$ & 87.69 & 28.08 & & 0.20 & 0.93 & 0.88 \\
\hline 高䀫層 & 0.4144 & $0.4666^{* *}$ & & & $0.616^{*}$ & 95.15 & 122.55 & & & 0.97 & 0.94 \\
\hline
\end{tabular}

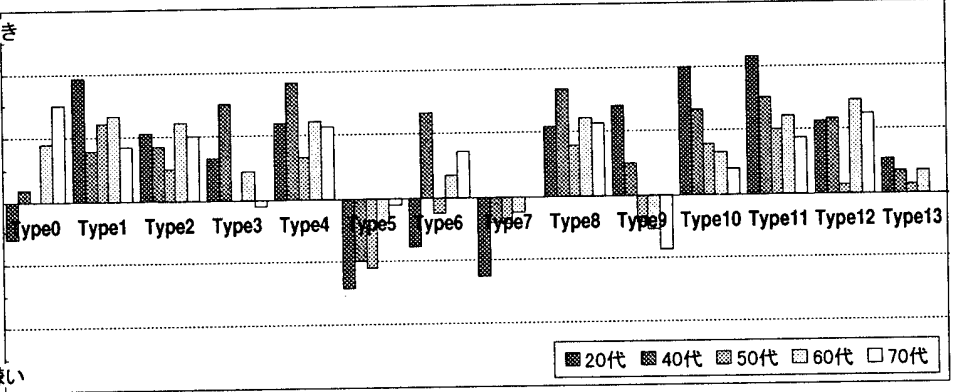

図 14 各年代好みの評定平均值

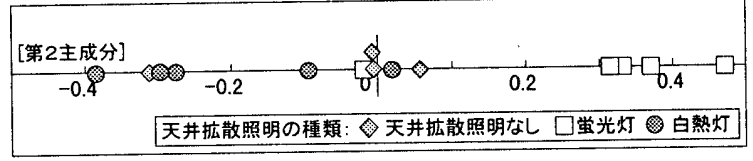

図15 各照明パターンの固有ベクトル

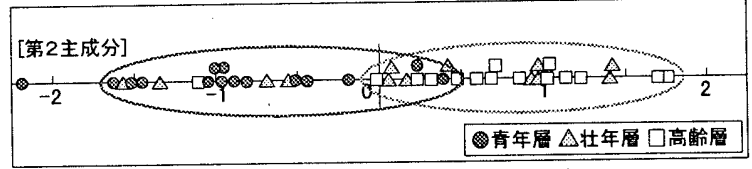

図 16 全被験者の主成分得点

るが、年齢層が高くなるにしたがって低下していく。逆に「活動性」 は好みとの相関が高くなり、年龄層による違いが表れていることが わかる。

さらに、好みと各因子の関係をより明確にするため、各層の好み の評定平均值を目的変数にとり、各因子の因子得点を説明変数とし て重回帰分析を行った。その結果を表5に示す。目的変数を説明す る際の貢献度の高さを表すF值をみると、青年層では「安らぎ」の みが高いが、年齢層が高くなるにしたがって「活動性」の貢献度が 上がり、高齢層では「活動性」が「安らぎ」を上回る。

これらのことから、青年層では「安らぎ」の因子得点が高いこと が好まれる条件であり、「活動性」の影響は少ないが、高齢層では 「安らぎ」活動性」ともに因子得点が高い照明パターンが好まれ、 「活動性」の影響が「安らぎ」よりも大きくなることがわかる。 4-4 好多の評価 
年齢層の違いによる照明に対する好みの差を明らかにするため、 被験者を 20 代〜 70 代（30代の被験者はなし）の年代別に分類し、 好みの評定平均值を求めたものを図 14 に示寸。とくに年代別によ る差が顕著なのはType0, 9, 10である。20代では好みの評価が低い Type 0 は 70 代では最も評価が高く、逆に 20 代では好まれている Type9は70代では最も評価が低い。同様に Type10 も大幅に好夕の 評価が低下している。この結果は、長町他 ${ }^{3)}$ においては、20〜49 といった比較的若い層に対して行った結果においては、白熱灯のほ うがムード性や気分安定性に優れているといった結果と一致してい る。本実験においては、全体的に、天井挔散照明が蛍光灯の照明パ ターンは、年代が上がると好みの評価が上がり、天井拡散照明が白 熱灯の照明パターンは逆に評価が下がる傾向がみられるという知見 を得た。

さらに、各層の傾向を明らかにするため、全被験者の好みの評定 值について、投入変数を総合化した尺度で表すことのできる解析法 である主成分分析を行ったところ、2つの主成分が抽出された。第 1 主成分については解釈ができなかったため、第2主成分について 各照明パターンの固有ベクトルをプロットし、図15に示す。蛍光 灯を用いた色温度の高い照明パターン值が大きく、白熱灯を用い た色温度の低いパターンは值が小さいことから、第2主成分は色温 度のファクターであると考えられる。こで全被験者の主成分得点 をプロットしたものを図16に示す。これをみると、青年層はマイ ナス方向に、高齢層はプラス方向に集まっていることがわかる。こ のことからも、青年層は白熱灯を用いた照明パターンを好み、高齢 層は蛍光灯を用いた照明パターンを好傾向があることがうかがえ る。

以上の結果から、高齢者にとってリビングにおける快適な照明条 件とは、『蛍光灯によるべース照明により部屋全体の「活動性」(明 るさ)を確保したうえで、局所照明、意匠照明により「安らぎ」(暖 かさ）を高める』ことである。本実験においては蛍光灯の天井拡散 照明EとブラケットA, フロアスタンドG, Hを点灯したType8がこれ にあたり、このパターンは高龄層だけでなく壮年層、蛍光灯を嫌う 傾向のある青年層においても好みの評価汃高く、様々な年代の居住 者が集まるリビングにおける照明として適していると考えられる。

\section{5. まとめ}

日本では昔から光を面としてとらえ、ヨーロッパでは光を点とし てとらえる文化の違いがある。また、戦後から現在までの日本の住 宅照明は全てむらなく明るく、照度レベルを上げることにより、安 心感や清潔感を得てきたが、最近では欧風の久タイルを取り入れ、 比較的陰影のある照明が好まれる傾向がある ${ }^{12)}$ 。

本実験においては各層の明るさ感には差がみられず、若年者と比 較して高龄者がグレアを感じているといら傾向もみられなかったこ とから、くつろぎを行う際に照明環境に求めるものの若年者と高跉 者の違いは、視機能の違いによる影響よりも、こういった光に対す るとらえ方、期待感の違いからくるものが大きいと考えられる。

高齞者の照明環境に対する好みの評価、明るさ感は単に照度レべ ルを上げることにより上昇するのではなく、一定の照度レベルを 保ったうえで多灯照明とすることが重要な条件であることが示唆さ れた。

\section{参考文献}

1）日本建築学会編 :「高齢者のための建築環境」、彰国社、1994.

2) 福田忠彦、斉藤進、高齢者の視覚特性、NHK 技研 R\&D、p. 48-55、1988 3) 長町三生、伊藤宏司、福場良之、辻 敏夫、田淵義彦、入江輝昭 : 室 内照明の情緒工学的研究、人間工学 Vol.21 No. 5、日本人間工学会、 1985.

4) 小林茂雄、中村芳樹、木津 努、乾正雄 : 空間の輝度分布が室内の明 るさ感に与える影響、日本建築学会計画系論文集 第 487 号、p. 3341、 1996.

5) 北村麻子、小林茂雄、中村芳樹、乾正雄 : 室内空間における行為と不 均一照明、照明学会全国大会講演論文集、p. 257-258、1994

6) 北村麻子、小林茂雄、中村芳樹、乾正雄 : 適材適光からみた行為と室 内照明の関係（その1）生活行為と室内空間の明るさ、日本建築学会 大会学術講演梗概集 (D)、p. 1931-1932、1994.

7) 宮澤縫衣子、中村芳樹、小林茂雄、中島大志 : 室内の明るさ分布が行 為の選択に与える影響 (その 1 明るさ分布と推察される行為の関 倸)、日本建築学会大会学術講演梗概集 (D - 1)、p. 333-334、1996.

8) 中島大志、中村芳樹、小林茂雄、宮澤縫衣子 : 室内の明るさ分布が行 為の選択に与える影響（その 2 行為内容を選択する場面における光 環境の効果)、日本建築学会大会学術講演梗概集（D-1）、 p. 335-336、 1996.

9) 石神光一朗、中村芳樹 : 光源の分光特性と室内の明るさ感評価、日本 建筑学会大会学術講演梗概集（D - 1)、p. 411-412、1996.

10)國嶋道子、梁瀬度子: 室内構成材の雾囲気への影響に関寸る研究 (1) 一設計計画的要因について一、人間工学 Vol. 20 No.6、日本人間 工学会、 1984 .

11) 國嶋道子、梁瀬度子: 室内構成材の雾囲気への影響に関する研究 (2) 一室内装備的要因について一、人間工学 Vol. 21 No.1、日本人間 工学会、 1985 .

12)戸山山みどり、斉藤進 : 職場における快適な視環境の設計、人間工学 Vol. 29 No. 2、日本人間工学会、1993.

13) 内田茂 : 閉空間に対寸る感覚に関寸る実験的研究 その 1 、日本建築 学会論文集 第 282 号、p. 113-122、1979.

14) 内田茂 : 閉空間に対する感覚に関する実験的研究 その2、日本建築 学会論文集 第 285 号、p. 117-125、1979.

15) 北村麻子、茶谷譲介、中村芳樹、乾正雄 : モデリング効果による室内 光環境の評価 (その1 評価図の作成)、日本建築学会大会学術講演梗 概集 (D)、p. 307-309、日本建築学会大会学術講演梗概集 (D)、p. 309308、1992.

16) 茶谷譲介、北村麻子、中村芳樹、乾正雄 : モデリング効果による室内 光環境の評価 (その2 実空間における光環境の評価)、日本建築学会 大会学術講演梗概集 (D)、p. 309-310、1992.

17) 望月菜穂子、中村芳樹、趙虹、乾正雄 : 行動セッティングを考慮した 室内輝度分布の心理的効果、(その1 シミュレーションを用いた印象 評価実験)、日本建築学会大会学術講演梗概集 (D)、p. 317-318、1992.

18）中村芳樹、望月菜穂子、乾正雄 : 行動セッティングを考慮した室内輝 度分布の心理的效果、(その 2 輝度分布と印象の関係)、日本建築学 会大会学術講演梗概集 (D)、p. 319-320、1992.

19) 小林茂雄、北村麻子、中村芳樹、乾正雄 : 適材適光からみた行為之室 内照明の関係（その2）生活行為と不均一照明、日本建築学会大会学 術講演梗概集 (D)、p. 1933-1934、1994.

20) 月刊 SUMAI. Vol. 13 No2、日本工業出版、1992.

21）中島龍興、近田玲子、面出董：「照明デザイン入門」、彰国社. 1995

22) 芝祐順：因子分析法第 2版、東大出版、1979.

23) 菅民郎：「多変量解析の実践」、現代数学社. 1993 . 